\title{
SMOKING : TOXIC EFFECTS 1N OSTEOARTHRITIS
}

\author{
$\mathscr{B y}$ \\ Reham M. Shaat, Afaf, M. Attia , Eman Abdel-Razek, \\ Adel. I. Abd-El Salam, M.M El-Defrawy
}

\section{Trom}

Physical Medicine, Rehabilitation and Rheumatology, Forensic Medicine,

Clinical Toxicology and General medicine Departments, Faculty of Medicine, Analytical Biochemistry faculty of science Mansoura University

\begin{abstract}
The material for the present study included 24 patients (18males \& 6femals) with osteoarthritis (OA) selected from Rheumatology and rehabilitation out patients clinic Mansoura University Hospital with age range from (45-67 years). 16 patients were heavy smokers consuming $>20$ cigarette /day for long duration $>15$ years while 8 patients were non smokers. 8 normal (non smokers) healthy volunteers with matched age and sex served as control. All patients were subjected to radiologic assessment of (OA) using Kellgren Lawrence grading scal, and clinical assessment including body mass index (BMI) and WOMAC (Western Ontario and McMaster universities) index of osteoarthritis. Using Perkins
\end{abstract}

Elmer atomic absorption spectrophotometry, both plasma cadmium (Cd) and lead $(\mathrm{Pb})$ levels were found to be significantly increased among patients with OA exposed to intoxication through heavy cigarette smoking for long duration. A+ve correlation was found between plasma $\mathrm{Cd} \& \mathrm{~Pb}$ levels and severity of $O A$. Also plasma $\mathrm{Cd} \& \mathrm{~Pb}$ levels were found to be significantly increased among, middle aged, slim (non obese) smokers with OA compared with elderly obese patients. In light of previous findings we can conclude that exposure to toxic effect of smoking for long duration may contribute to pathogenesis of OA even in absence of some other risk factors such as older age and obesity

MANSOURA MEDICAL JOURNAL 


\section{Introducstion and Aim of work}

Tobacco plant naturally absorps, accumulate and concentrate toxic elements as cadmium ( $\mathrm{Cd}$ ) and lead $(\mathrm{Pb})$. Most probably from soil fertilizers or pesticides (Wagner: 1993) other environmental factors that may influence the uptake of toxic elements by tobacco plant include $\mathrm{pH}$ of soil, contaminated irregated water and sewage sludge used as fertilizers. $\mathrm{Cd}$ and $\mathrm{Pb}$ readily pass from inhaled smoke to the blood stream (Csalari.; and Szantai. 2002). These heavy metals are known to have toxic effects not only to bones but also to cartilage (Milachowski, 1988). Osteoarthritis is the most common form of arthritis (Lawrence et. al 2008) while some risk factors for osteoarthritis (OA) are known such as older age and obesity (Zhang, and jardan 2008). The disease process remains poorly understood and no effective disease modifying treatments are currently available. Regional difference in arthritis prevelance are suggestive of possible contribution of other factors. Haemochromatosis a genetic disorder of heavy metal (iron) metabolism is frequently associated with arthropathy with features similar to those with (OA), Sokoloff (1985) and Jordan (2004). Putting these observations in consideration, we considered the possibility of heavy exposure to toxic effects of smoking for long duration as novel risk factor for (OA).

\section{MATERIAL AND METHODS}

The material for the present study included 24 patients with osteoarthritis (OA) selected from rheumatology and rehabilitation outpatients clinic of Mansoura University Hospital, including 18 males and 6 femals with age ranged from $45-67$ years. Eight normal (non smokers) healthy volunteers with matched age and sex served as control group. All patients and volunteers were subjected to the following investigations.

1) Radiological assessment of osteo-arthritis

Using Kellgren Lawrence grading scale (Kellgren and Lawrence; 1957).

Grade I : Doubtful narrowing of joint space and possible osteophytic lipping.

Grade II : Definite osteophytes and definite narrowing of joint space.

Grade III : Moderate multiple osteophytes, definite narrowing of joint space, some sclerosis and possible deformity 
of bone contour.

Grade IV : Large osteophytes , marked narrowing of joint space, severe sclerosis and definite deformity of bone contour.

\section{2) Clinical data}

Including age, sex, personal habbits (smoking), body mass index (BMI) and clinical assessment of osteoarthritis (OA) using WOMAC (Western Ontario and McMaster university index) (Bellamy 1989).

Total score : (Minimum score $=0$ maximum score $=96$ ).

3) Determination of plasma $\mathrm{Cd}$ and $\mathrm{Pb}$ concentrations using Perkins Elmer atomic absorption spectrophotometry (Stockwell and Corns. 1993) were done for all patients and volunteers.

4) Patients with osteoarthritis included 8 non smokers (6femals and 2 males) while 16 males were heavy smokers consuming $>20$ cigarettes /day for long duration $>$ 15 years.

5) Among heavy smokers 7 patients were elderly $>60$ years and obese with body mass index (BMI) $>30$ while 9 patients were middle aged (45-56) years, slim (non obese) with BMI (23-26).

6) Assessment of osteoarthritis among heavy smokers according to WOMAC index score and Kellgren Lawrence radiologic grading scale revealed.

i. Mild OA in 8 patients with radiologic scale (Grade I \& II) and WOMAC index total score $<30$.

ii. Moderate and severe disease in 8 patients with radiologic scale (Grade III \& IV) and WOMAC index total score $(>60)$

* Statistical analysis was done using Student $\mathrm{T}$ test and pearson correlation test Rifenburgh (1999).

\section{RESULTS}

1. Plasma $\mathrm{Cd} \& \mathrm{~Pb}$ concentrations were significantly increased $(P=<0.001)$ among heavy smokers patients with osteoarthritis compared with healthy volunteers (Table I).

2. plasma $\mathrm{Cd}$ and $\mathrm{Pb}$ level were insignificantly increased among non smokers OA patients compared with control group (table II).

3. plasma $\mathrm{Cd}$ and $\mathrm{Pb}$ levels in patients with $(O A)$ were significantly increased $\quad(P=<0.001)$ among heavy smokers compared with non smokers (table III).

4. plasma $\mathrm{Cd}$ and $\mathrm{Pb}$ levels were significantly increased among

MANSOURA MEDICAL JOURNAL 


\section{SMOKING : TOXIC EFFECTS IN OSTEOARTHRITIS}

middle aged - non-obese smokers OA patients compared with elderly obese smokers (table IV).

5. A+ve correlation was observed between plasma $\mathrm{Cd}$ and $\mathrm{Pb}$ concentrations and severity of osteoarthritis in patients heavily exposed to toxic effects of smoking for long duration (Table V).

Table (I): Plasma $\mathrm{Cd}$ and $\mathrm{Pb}$ levels in patients with OA (smokers) compared with control group

\begin{tabular}{|l|c|c|c|}
\hline \multirow{2}{*}{$\begin{array}{c}\text { Plasma Cd \& Pb } \\
\text { concentration }\end{array}$} & $\begin{array}{c}\text { (OA) patients } \\
\text { (smokers) }\end{array}$ & Control group & \multirow{2}{*}{ P value } \\
\cline { 2 - 3 } & $\mathrm{M} \pm \mathrm{SD}$ & $\mathrm{M} \pm \mathrm{SD}$ & \\
\hline $\mathrm{Cd} \mu \mathrm{gm} / \mathrm{dL}$ & $8.6 \pm 1.3$ & $0.23 \pm 0.02$ & $<0.001$ \\
\hline $\mathrm{Pb} \mu \mathrm{g} / \mathrm{dL}$ & $32 \pm 1.2$ & $12 \pm 3.6$ & $<.001$ \\
\hline
\end{tabular}

(Table II): Plasma $\mathrm{Cd}$ and $\mathrm{Pb}$ levels in patients with $\mathrm{OA}$ (non smokers) compared with control group

\begin{tabular}{|l|c|c|l|}
\hline \multirow{2}{*}{$\begin{array}{c}\text { Plasma Cd \& Pb } \\
\text { concentration }\end{array}$} & $\begin{array}{c}\text { (OA) patients } \\
\text { (Non smokers) }\end{array}$ & Control group & \multirow{2}{*}{ P value } \\
\cline { 2 - 3 } & $\mathrm{M} \pm \mathrm{SD}$ & $\mathrm{M} \pm \mathrm{SD}$ & \\
\hline $\mathrm{Cd} \mu \mathrm{gm} / \mathrm{dL}$ & $0.28 \pm 0.6$ & $0.23 \pm 0.02$ & $>0.005$ \\
\hline $\mathrm{Pb} \mu \mathrm{gm} / \mathrm{dL}$ & $13.2 \pm 0.4$ & $12 \pm 3.6$ & $>.005$ \\
\hline
\end{tabular}


(Table III): Plasma $\mathrm{Cd}$ and $\mathrm{Pb}$ levels in patients wit $\mathrm{OA}$ (smokers versus non smokers)

\begin{tabular}{|l|c|c|c|}
\hline \multirow{2}{*}{$\begin{array}{c}\text { Plasma Cd \& Pb } \\
\text { concentration }\end{array}$} & $\begin{array}{c}\text { patients with (OA) } \\
\text { smokers }\end{array}$ & $\begin{array}{c}\text { patients with (OA) } \\
\text { Non smokers }\end{array}$ & \multirow{2}{*}{ P value } \\
\cline { 2 - 3 } & $\mathrm{M} \pm \mathrm{SD}$ & $\mathrm{M} \pm \mathrm{SD}$ & \\
\hline $\mathrm{Cd} \mu \mathrm{gm} / \mathrm{dL}$ & $8.6 \pm 1.3$ & $0.28 \pm 0.6$ & $<0.001$ \\
\hline $\mathrm{Pb} \mu \mathrm{gm} / \mathrm{dL}$ & $32 \pm 1.2$ & $13.2 \pm 0.4$ & $<0.001$ \\
\hline
\end{tabular}

(Table IV): Plasma Cd and Pb levels in patients wit OA (smokers) elderly obese versus middle aged slim (non obese) patients

\begin{tabular}{|l|c|c|c|}
\hline $\begin{array}{c}\text { Patients with OA } \\
\text { (smokers) }\end{array}$ & $\begin{array}{c}\text { Middle aged non- } \\
\text { obese patients }\end{array}$ & $\begin{array}{c}\text { Elderly obese } \\
\text { patients }\end{array}$ & \multirow{2}{*}{ P value } \\
\hline $\begin{array}{l}\mathrm{Cd} \& \mathrm{~Pb} \text { plasma } \\
\text { concentration }\end{array}$ & $\mathrm{M} \pm \mathrm{SD}$ & $\mathrm{M} \pm \mathrm{SD}$ & \\
\hline $\mathrm{Cd} \mu \mathrm{g} / \mathrm{dL}$ & $9.8 \pm 0.41$ & $7.4 \pm 0.32$ & $<0.05$ \\
\hline $\mathrm{Pb} \mu \mathrm{g} / \mathrm{dL}$ & $36 \pm 0.6$ & $28 \pm 0.23$ & $<0.05$ \\
\hline
\end{tabular}

(Table V): $\mathrm{Cd} \& \mathrm{~Pb}$ plasma levels in correlation with severity of $(\mathrm{OA})$ in patients exposed to toxic effects of smoking for long duration

\begin{tabular}{|l|c|c|c|}
\hline $\begin{array}{c}\text { Patients with } \\
\text { OA (smokers) }\end{array}$ & $\begin{array}{c}\text { Patients Grade I \& II } \\
\text { (radiologic scale) \& } \\
\text { WOMAC index score } \\
<\mathbf{3 0} \text { (Mild Disease) }\end{array}$ & $\begin{array}{c}\text { Patients Grade III \& IV } \\
\text { (radiologic scale) \& WOMAC } \\
\text { index score >60 (Moderate } \\
\text { and severe Disease) }\end{array}$ & \multirow{2}{*}{ P value } \\
\cline { 1 - 3 } $\begin{array}{l}\mathrm{Cd} \& \mathrm{~Pb} \text { plasma } \\
\text { concentration }\end{array}$ & $\mathrm{M} \pm \mathrm{SD}$ & $9.9 \pm 0.3$ & \\
\hline $\mathrm{Cd} \boldsymbol{\mu g} / \mathrm{dL}$ & $7.6 \pm 0.21$ & $37.2 \pm 2.4$ & $<0.05$ \\
\hline $\mathrm{Pb} \mu \mathrm{g} / \mathrm{dL}$ & $27.3 \pm 2.8$ & & \\
\hline
\end{tabular}




\section{DISCUSSION}

Tobacco leaves naturally accumelate and concentrate relatively high levels of $\mathrm{Cd}$ and $\mathrm{Pb}$ and therefore smoking of tobacco is an important source for these toxic metals exposure (Kazi et al 2009). In the present study both plasma $\mathrm{Cd}$ and $\mathrm{Pb}$ concentrations were found to be significantly increased in OA patients exposed to intoxication through heavy cigarette smoking for long duration of time $>15$ years. Several studies showed a direct connection between $\mathrm{Cd}$ intoxication and bone damage even minimal exposure is supposed to cause skeletal demineralization (Nordberg 2004 and Jarup et al. 1998) cadmium is heavy metal poison with severe risk to human health (Johannes et al. 2006). Cadmium is widely used in industrial processes phosphate fertilizers also show big Cd load (Jarup L 2003). The major source of $\mathrm{Cd}$ intoxication is cigarette smoke, the human lung absorbs $40-60 \%$ of $\mathrm{Cd}$ in tobacco smoke. Smokers generally have cadmium blood level 4-5 times those of non smokers (Goyer 1996).Cadmium alters calcium and phosphorous metabolism thus contributing to arthritis, osteoporosis and neuromuscular disease (Tandon et al. 2001). Cd can deposit in bone from respiratory exposure, it may deplete glutathione resulting in the production of injurious reactive oxygen species such as super oxide, hydrogen peroxide and hydroxyl radicles (Nordberg 2004). Recent study suggest that even low level of $\mathrm{Cd}$ exposure will decrease the viability of osteoblast meanwhile Cd significantly stimulate the formation of osteoclasts (Chen et al. 2011). Approximately $95 \%$ of total body $(\mathrm{Pb})$ burden in adults is stored in bone and has half life of decades (Barry, Mossman 1970) which contributes as mush as $65 \%$ to measured blood level (Holz et al. 2007). $\mathrm{Pb}$ deposition has been observed in both cartilage and bone in human OA (Wittmers ea al 1998). The toxic element $(\mathrm{Pb})$ and polycyclic aromatic hydrocarbons in cigarette smoke interact with cells of Skeletal system adversely affecting bone and cartilage (Barry et al. 2008). Recent study reported arthropathy caused by lead bullet causing multiple metallic fragments in and around joint space as well as signs of OA. Physical examination findings were consistant with moderate osteoarthritis removal of $(\mathrm{Pb})$ intra articular forign body is indicated even if the material is not believed to mechanically interfere with

Vol. 42, No. 1 \& 2 Jan. \& April, 2013 
joint motion. (Barry et al 2008).

In the present study a +ve correlation was found between plasma $\mathrm{Cd}$ \& $\mathrm{Pb}$ levels and severity of $\mathrm{OA}$ (assessed according to Kellgren Lawrence grading scale and WOMAC index) in patients heavily exposed to toxic effects of smoking. Also plasma $\mathrm{Cd} \& \mathrm{~Pb}$ levels were found to be significantly increased among heavy smokers, middle aged slim, (non obese) patients with $\mathrm{OA}$ compared with elderly obese patients. In light of previous findings we can conclude that exposure to toxic effects of smoking for long duration may contribute to pathogenesis of $O A$ even in absence of some other risk factors such as older age and obesity.

\section{REFERENCES}

1. Barry PS, Mossman DB (1970) : lead concentrations in human Tissue Br.j.ind. Med 27:339-351.

\section{Barry S L, lafuente MP, Martiez}

SA (2008) : Arthropathy caused by bullet, in dog: $J$ Am Vet Med Assoc 15; 232(6) 886-8.

3. Bellamy N (1989) : Experience with WOMAC Osteo- arthritis index. Semin Arthritis Rheumatism 18(supplement 2) 14-17.

4. Chen X, Zhu G, jim T, Zhouz, Gu S, Qiu J Xiao H (2011) : cadmium stimulates, the osteoclastic differentiation :Biol Trace Element Res $1: 1$.

5. Csalari. j; Szantai.K (2002) : Transfere rate of $\mathrm{Cd}, \mathrm{Pb}$ zinc and iron from the Tobacco cut of the most popular Hungarian cigarettes brands to the combustion products : Acta Aliment 31 : 279-88.

6. Goyer RA (1996) : Toxic effects of Metals: Klasen CD, (Editor) Casarett and Doulls Toxicology. The basic science of poisons Vol 5 New York McGraw Hill P 691736.

7. Holz J D, Sheu Tj, Drissi H, Matswzawa M, Zuscik Mj, Puzas j E (2007) : Birth defects Res, Embryo to day 81(1) 41-50.

MANSOURA MEDICAL JOURNAL 


\section{SMOKING : TOXIC EFFECTS IN OSTEOARTHRITIS}

8. Jarup L (2003) : Hazards of heavy metal contamination: Br med Bull 68: 167-182.

9. Jarup L, Bergland $M$, Elinder CG, Nordberg G Vahter M (1998) : Health effects of cadmium exposures : Scand, work Environ Health 24 supp (1) 1-51.

10. Johannes Godt, Franziska Scheidig, Christian gnosse, Siestrup, Vera Esche, Paul Brandenberg, Andria Reich and David A Cronberg (2006) : The toxicity of cadmium and resulting hazards for human health $\mathrm{J}$ of occupational Medicine and Toxicology $1: 22$.

11. Jordan j M (2004) : Arthritis in Haemochromatosis or iron storage disease Curr Opin Rheumatol 16: 6266.

12. Kazi T.G; Afridi. H.I, Kazi . N (2009) : Toxic metal distribution in different components of cigarettes $\mathrm{J} \mathrm{Haz}$ ard Mater : 163 (302-307).
13. Kellgren $\mathrm{JH}$; Lawrence j $\mathrm{S}$; (1957) : Radiological assessment of osteoarthritis : Ann Rheum Dis 16(4): 494502.

14. Lawrence RC ; felson DT, Helmick CG; Amold. L.M, choi H, Fey O.R.A, Gabriel .S Hirsh R, Hochberg MC, Hunder GG, Jordan j.M, Katz jN, Kremers HM , Wolf $F$ (2008) : National arthritis data work group estimates of the prevelance of arthritis and other rheumatic conditions in US Arthritis Rheum part II $58: 26-35$.

15. Milachowski, KA (1988) : Investigation of ischaemic Necrosis of the femoral head with trace elements : Int Orthop 12: 323-330.

16. Nordberg G F (2004) : Cdmium and health in 21 century historical remarks and trends for the future : Biometal 17(5) 488-489.

17. Riffeuburg R.H (1999) : Statistics in medicine Academic 
press chapter (15) 311 320.

18. Sokoloff L (1985) : Endemic forms of osteoarthritis Clin Rheum Dis 11: 187-212.

19. Stockwell . P.B. and Corns. W.T (1993) : The role of atomic absorption fluorescence environmental monitoring trace elements analysis : j automatic chemistry : 15 (79-84).

20. Wagner G j (1993) : Accumulation of cadmium in crop plants and its consequences to human Health; Adv Agron 51 : 173-213.

21. Wittmers LE, Aufderheide AC, Wallgren j, Rapp G Jr, Alich A (1988) : Lead in bone, Distribution of lead in human Skeleton: Arch Environ Health 43: 381391.

22. Zhang $Y$, jardan j $M$ (2008) : Epidemiology of osteoarthritis : Rheum Dis Clin North Am 34: 515-529. 


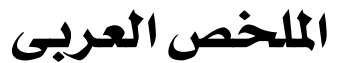

\section{التدخين وآثاره السامة فى مرضى \\ التهاب وخشونة المفاصل}

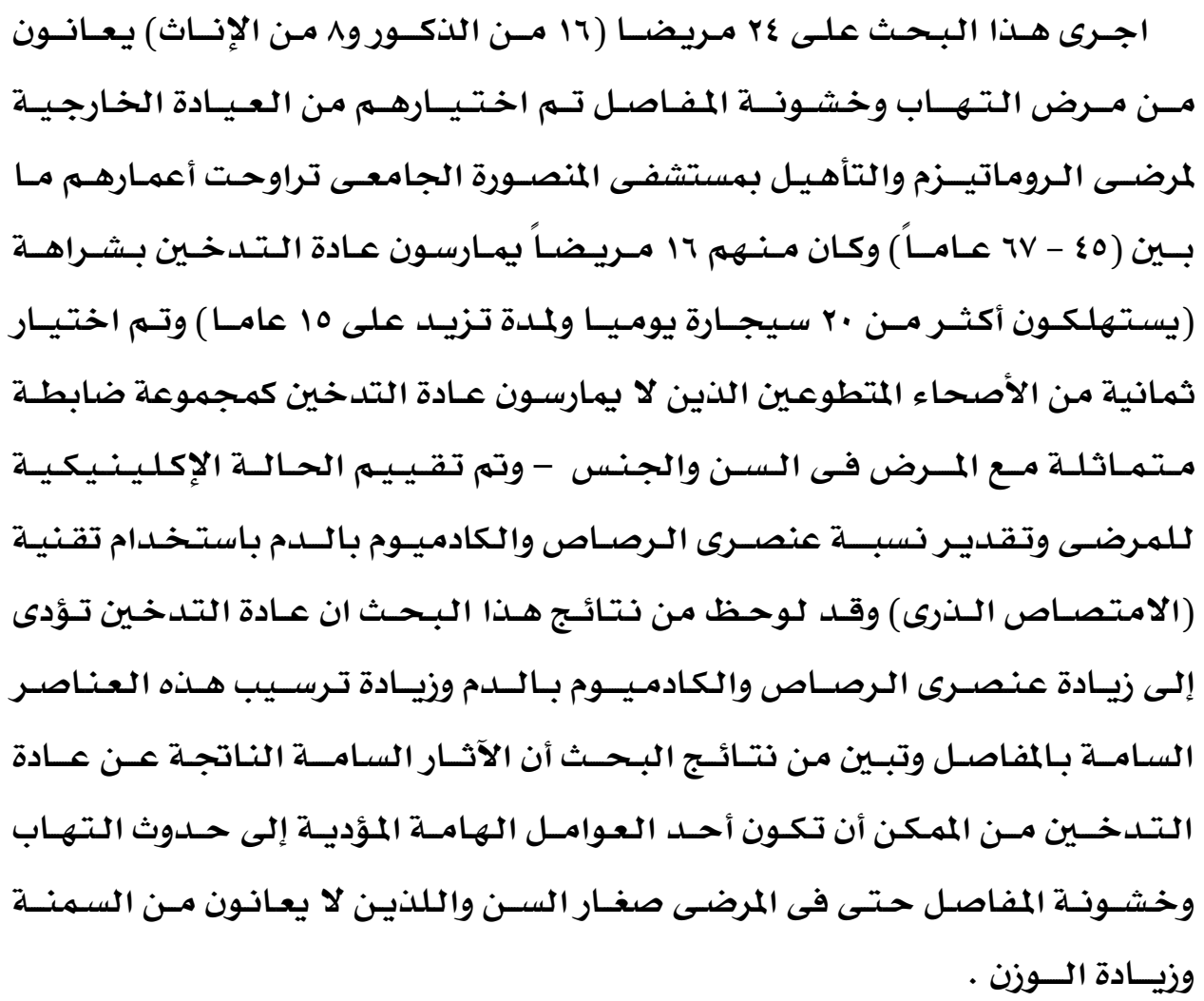

